\title{
ANALISIS KESALAHAN SISWA KELAS VIII SMP DALAM MENYELESAIKAN SOAL CERITA PADA MATERI PERBANDINGAN DITINJAU DARI GENDER
}

\author{
Yuni Agnesti ${ }^{1}$, Risma Amelia ${ }^{2}$ \\ IKIP Siliwangi, Jl. Terusan Jenderal Soedirman Cimahi, Jawa Barat, Indonesia \\ yuniagnesti168@gmail.com
}

\begin{abstract}
The study was conducted at Pasundan Rongga Middle School in November 2019. The purpose of the study was to determine the form of mistakes made by students of class VIII A in solving story problems. Analysis of the data used refers to the analysis of errors in the steps of working on the problems, whether students can solve correctly, can solve in accordance with the instructions asked, and whether students can solve problems with mathematical modeling. The subjects of the study were students of class VIII A. Sample selection was based on male and female students. Based on research, there are several forms of mistakes made, including male students' errors in question number 1 as much as $85.56 \%$, number 2 as much as $91.67 \%$, number 3 as much as $88.67 \%$. While the Error of female students in question number 1 was $55.56 \%$, number 2 was $45.83 \%$, number 3 was $50 \%$. Furthermore, it was concluded that male students have a higher error rate than female students. Because when interviewed also said that in the problem story is low in mastering the questions and calculations, lack of understanding what the meaning of the questions and what to look for from the questions.
\end{abstract}

Keywords : Error Analysis, Comparison

\begin{abstract}
Abstrak
Penelitian dilakukan di SMP Pasundan Rongga pada bulan November 2019. Tujuan dari penelitian adalah untuk mengetahui bentuk kesalahan yang dilakukan siswa kelas VIII A dalam menyelesaikan soal cerita. Analisis data yang digunakan mengacu pada analisis kesalahan pada langkah-langkah mengerjakan soal, apakah siswa bisa menyelesaikan dengan tepat, bisa menyelesaikan sesuai dengan intruksi soal yang diminta, dan apakah siswa bisa menyelesaikan soal dengan pemodelan matematikanya. Subjek penelitian adalah siswa kelas VIII A. Pemilihan sampel didasarkan pada siswa laki-laki dan perempuan. Berdasarkan penelitian, terdapat beberapa bentuk kesalahan yang dilakukan, diantaranya kesalahan siswa laki-laki pada soal nomor 1 sebanyak 85,56\%, nomor 2 sebanyak 91,67\%, nomor 3 sebanyak 88,67\%. Sedangkan Kesalahan siswa perempuan pada soal nomor 1 sebanyak 55,56\%, nomor 2 sebanyak 45,83\%, nomor 3 sebanyak 50\%. Selanjutnya diperoleh kesimpulan, bahwa siswa laki-laki memiliki tingkat kesalahan yang tinggi dibanding siswa perempuan. Karena pada saat diwawancara juga mengatakan bahwa di dalam soal cerita itu rendah dalam menguasai soal dan perhitungan , kurang memahami apa makna dari soal dan apa yang harus dicari dari soal-soal tersebut.
\end{abstract}

Kata Kunci: Analisis Kesalahan, Perbandingan

\section{PENDAHULUAN}

Matematika merupakan bagian bidang studi yang memiliki peranan penting dalam dunia pendidik dan dapat digunakan untuk menyelesaikan permasalahan-permasalahan yang sering kita jumpai dalam kehidupan sehari-hari (Manalu,S,C,A., Zanthy,S,L., 2020) Matematika adalah ratu ilmu dimana semua ilmu pengetahuan yang dipelajari pasti menggunakan matematika. Menurut Isnaeni, Fajriyah, Risky, Purwasih, \& Hidayat, (Yusdiana \& Hidayat, 2018) pendidikan matematika dapat mendorong masyarakat untuk selalu maju, terbukti dengan adanya perkembangan teknologi modern. Oleh karena itu, belajar matematika dengan baik merupakan langkah pertama dalam penguasaan konsep. 
Pemahaman adalah tingkat kemampuan yang mengharapkan siswa mampu memahami arti atau konsep, situasi serta fakta yang diketahuinya. Jadi, dalam penguasaan konsep tersebut, siswa sangat dituntut karena disamping bisa mempelajari matematika, siswa juga harus benar-benar memahami dan bisa membuktikan bahwa belajar matematika itu tidak hanya mempelajari dan bisa berhitung saja (Mentari Dini , Tommy Tanu Wijaya, 2018).

Konsep dalam matematika menurut Hudojo (Zulfah, 2017) adalah "suatu ide/gagasan yang dibentuk dengan memandang sifat-sifat yang sama dari sekumpulan eksemplar yang cocok. Dengan mengambil adanya sekumpulan eksemplar sebagai kriteria, kita mengidentifikasi konsep. Apabila kita dapat menemukan lebih dari satu eksemplar dari suatu ide/gagasan, kita namakan suatu konsep". Sedangkan menurut Niasih (Rachman, F, A., Saripudin 2020) menyatakan bahwa kurangnya penguasaan konsep, rendahnya keterampilan siswa dalam menarik kesimpulan, siswa kurang cermat dalam menyelesaikan soal, dan siswa menjawab tidak disertai alasan yang jelas. Seperti halnya pembelajaran di MAN Kota Cimahi, didapatkan siswa yang masih kesukaran dalam memahami konsep yang diajarkan. Hal ini yang melahirkan soal yang diberjakan terjadi kesalahan (Rachman, F, A., Saripudin 2020). Kesalahan yang terlihat pada siswa salah satunya pada materi trigonometri, khususnya pada subab aturan sinus, aturan cosinus, luas segitiga yang membutuhkan pemahaman konsep dan ketelitian yang tinggi. Berdasarkan hasil wawancara kepada siswa kelas XI MIPA 3 MAN Kota Cimahi, ternyata siswa merasa kesulitan dalam mengerjakan soal trigonometri, karena tidak tahu memakai rumus yang benar dalam mengerjakan soal trigonometri.

Pada saat ini banyak siswa berasumsi bahwa tujuan matematika adalah hanya untuk pintar berhitung. Maka dari itu matematika sangat penting dan dipelajari pada tiap jenjang pendidikan, hal ini ditegaskan oleh Suherman (2003) menyatakan bahwa "Hal yang penting bagi siswa untuk bekal pengetahuan yang bertujuan membentuk sikap serta pola pikirnya adalah matematika yang dipelajari melalui pendidikan formal''.Selain dipelajari melalui pendidikan formal, matematika juga harus terus dipelajari pada jenjang pendidikan yang tinggi, jadi intinya matematika itu tidak cukup saja dipelajari sampai SD,SMP,dan SMA saja.

Matematika memiliki karakteristik yang berbeda dengan mata pelajaran lain, obyek matematika pada dasarnya adalah abstrak.Keabstrakan matematika misalnya ada pada penggunaan simbol-simbol. Sehingga menimbulkan banyaknya siswa yang mengalami kesulitan belajar pada bidang yang banyak berkaitan dengan angka-angka.Atiqa, Y. Dan Kusrini (Hamidah,D., Putri,I,I,R., Somakim., 2018) mengatakan kendalanya adalah matematika memiliki karakteristik yaitu mempunyai objek yang bersifat abstrak, sehingga dapat menyebabkan banyak siswa yang sulit terhadap belajar matematika dan siswa mengalami kesulitan ketika mengubah soal cerita menjadi model matematika.Makadari itu dalam menyelesaikan soal cerita matematika sangatlah memerlukan suatu kemampuan untuk memecahkan masalah matematika tersebut,perlunya kemampuan berkomunikasi, dan diperlukan pemahaman yang sangat jeli dan berkreativitas yang tinggi. 
Menurut Khasanah (Toha, dkk 2018) soal cerita matematika adalah suatu soal uraian yang menuntut siswa mampu memahami dan menafsirkan pada soal yang pemecahannya memerlukan keterampilan dan kejelian. Selanjutnya selain siswa dituntut untuk mampu memahami terhadap masalah soal cerita matematika tersebut, siswa juga harus bisa memahami dan dapat mengubahnya ke dalam model matmatika karena di dalam soal cerita tidak hanya diperlukan jawaban yang benar dan tepat saja tetapi langkah-langkah dan prosesnyapun sangat diperlukan dalam menyelesaikan soal cerita.

Kadir (Fitria, dkk 2018) mengemukakan bahwa "Pembelajaran matematika dimaknai sebagai pembelajaran yang permasalahannya hanya dapat diselesaikan dengan satu cara dan hanya mendapatkan satu hasil". Suasana ini menjadi sangat sistematis merasuk pada diri siswa, manakala pandangan guru matematikanya di SD sama dengan pandangan guru di sekolah jenjang selanjutnya. Pandangan semacam ini semakin intens bila dari buku yang mereka baca menghasilkan persepsi yang seragam pula.Dengan demikian guru dituntut untuk mengkemas suatu pembelajaran secara optimal, dan yang paling utama adalah melibatkan siswa secara aktif. Jadi dalam pembelajaran matematika memang siswa sangat dituntut untuk terlibat aktif karena dalam proses pembelajaran itu tidak hanya seorang guru saja guru saja yang terus menerus menjelaskan atau memaparkan terhadap suatu materi, makadari itu diperlukan suatu kemampuan pemecahan masalah, dan kemampuan komunikasi agar di dalam proses pembelajaran tidak hanya metode ceramah saja yang digunakan oleh seorang guru tersebut.

Kemampuan pemecahan masalah dapat membantu siswa dalam mengerjakan suatu masalah matematika yang berbentuk soal cerita, membuat siswa lebih paham mengenai konsep matematika, serta dapat meningkatkan kemampuan berpikir siswa dalam menyelesaikan suatu masalah matematik non rutin sesuai dengan langkah-langkah yang tepat. Kurangnya kemampuan tersebut mengakibatkan kegiatan belajar mengajar matematika tidak mencapai tujuan dengan baik. Soal pemecahan masalah matematis berbeda dengan soal matematika yang biasa diterima siswa di kelas, karena proses atau langkah-langkah untuk memecahkan masalahnya berbeda (Indahsari,N,i., Situmorang,C,J., Amelia,R.,). Di dalam Kemampuan pemecahan masalah itu selain untuk membuat siswa lebih paham mengenai konsep matematika, juga bertujuan untuk meningkatkan kemampuan berpikir siswa terhadap penyelesaian soal cerita karena di dalam soal cerita sangatlah diperlukan suatu kemampuan yang bisa memecahkan suatu permasalahan dalam matematika.Kemampuan pemecahan masalah sangat terkait dengan kemampuan siswa dalam membaca dan memahami bahasa soal cerita, menyajikan dalam model matematika, merencanakan perhitungan dari model matematika, serta menyelesaikan perhitungan dari soal-soal yang tidak rutin. Pencapaian kemampuan pemecahan matematika memerlukan komunikasi matematika yang baik, dengan adanya interaksi yang seimbang antara siswa dengan siswa, atau pun siswa dengan guru (Fitria,dkk 2018).

Dalam membaca dan memahami soal cerita, diperlukan kemampuan untuk memecahkan masalah dan komunikasi yang seimbang karena antara siswa dan guru itu harus bisa melakukan interaksi dengan baik supaya dalam proses pembelajaran maupun dalam proses penyelesaian soal cerita bisa diselesaikan dengan benar dan tepat.Menurut Pimta (Mulyanti,R,N., Yani., Amelia,R., 2018) 
pemecahan masalah bukan hanya menjadi tujuan dari pembelajaran matematika, tetapi merupakan inti dalam pembelajaran matematika. Siswa yang sering dilatih dan dibiasakan dalam menyelesaikan atau memecahkan permasalahan matematika, kemampuan berpikirnya akan berkembang, selain kemampuan berpikirnya yang berkembang, kemampuan dasar dalam menyelesaikan masalah metematika pun akan berkembang, tetapi bukan hanya dalam menyelesaikan permasalahan matematika saja, namun dalam menyelesaikan permasalahan dalam kehidupan sehari-hari pun mereka dapat menyelesaikannya tanpa kendala (Mulyanti,R,N., Yani,N., Amelia,R., 2018).

Dalam kegiatan pembelajaran matematika dibutuhkan kemampuan komunikasi matematis. Komunikasi matematis itu sendiri merupakan kemampuan untuk mengungkapkan ide atau gagasan matematis baik secara lisan maupun tulisan (Azhari,N,D., Rosyana,T., Hendriana,H., 2018). Kemampuan komunikasi memang sangatlah diperlukan dalam menyelesaikan suatu permasalahan matematika karena di samping dapat memecahkan suatu permasalahannya secara verbal, siswa dituntut harus bisa merepresentasikan dan berkomunikasi dengan baik terhadap proses pembelajaran matematika maupun dalam proses menyelesaikan masalah matematika terutama dalam penyelesaian soal yang berbentuk soal cerita.

Hulukati (Azhari,N,D., Rosyana,T., Hendriana,H., 2018) mengatakan komunikasi matematis merupakan kemampuan dalam mengekspresikan, menginterpretasi, mengevaluasi ide-ide dan notasi matematika melalui tulisan, lisan, serta mendemonstrasikannya secara verbal. Karena kurangnya kebiasaan pendidik memberikan soal-soal non-rutin, kemampuan pemecahan masalah matematik siswa di kelas sangat tidak optimal, meskipun pendidik telah berusaha menuntun siswa menyelesaikannya, hal tersebut disebabkan karena soal-soal yang diberikan pendidik disekolah cenderung bersifat konvergen, jawaban dan strategi penyelesaiannya tunggal. Padahal tujuan pembelajaran matematika yang tingkatannya paling tinggi adalah pemecahan masalah, untuk itu sudah seharusnya siswa mampu mengajukan dugaan dan memanipulasi masalah non-rutin yang diberikan guru.

Kemampuan komunikasi matematis dan kemampuan pemecahan masalah merupakan bagian yang cukup penting dalam proses pembelajaran matematika karena kemampuan komunikasi dan kemampuan pemecahan masalah matematik siswa dalam menyelesaikan soal cerita merupakan salah satu kemampuan matematis yang penting untuk dimiliki dan dikembangkan oleh siswa yang belajar matematika. Hal ini sesuai dengan tujuan penelitian yang dilakukan di SMP Pasundan Rongga, di sekolah tersebut kurangnya Kemampuan komunikasi matematis dan kemampuan pemecahan masalah sehingga banyak siswa yang mengeluhkan terhadap penyelesaian soal cerita karena mereka tidak bisa memahami soal dengan baik, dan pada saat siswa mengerjakan soal cerita tersebut, siswa kelihatannya malas untuk mengerjakan, malas untuk membaca, dan bahkan ada siswa yang mengatakan bahwa belajar matematika itu untuk apa dan apa pentingnya kita belajar materi perbandingan.

Menurut Abdurrahman (Oktaviana,D 2018) alasan perlunya mempelajari matematika sebab matematika merupakan (1)sarana berpikir yang jelas dan logis, (2)sarana untuk memecahkan masalah kehidupan sehari-hari, (3)sarana mengenal pola-pola hubungan dan generalisasi pengalaman, (4)sarana 
untuk mengembangkan kreativitas, dan (5)sarana untuk meningkatkan kesadaran terhadap perkembangan budaya. Karena perannya yang sangat penting, sehingga matematika dipelajari sampai dengan jenjang pendidikan tinggi.

Secara matematika perbandingan berarti sebuah pernyataan kesamaan antara dua rasio, dan biasanya ditulis sebagai $\frac{a}{b}=\frac{c}{d}$. Belajar materi Perbandingan sangatlah penting untuk kita pelajari karena sebenarnya terdapat beberapa manfaatnya jika dikaitkan dalam kehidupan sehari-hari, contohnya kegunaan perbandingan dalam kehidupan sehai-hari yaitu : Untuk menghitung jarak kota di seluruh dunia supaya menghitung tidak sulit, untuk pembuatan peta, untuk pembuatan denah lokasi rumah, untuk membuat maket gedung, dan lain-lain.

Namun kenyataannya kesulitan siswa dalam mengkomunikasikan ide-ide matematisnya masih sering terjadi. Hal ini sejalan dengan hasil pengamatan peneliti saat melaksanakan Program Pengalaman Lapangan (PPL) di SMA Negeri 2 Pontianak diketahui bahwa banyak siswa mengalami kesulitan dalam menyelesaikan soal cerita yang membutuhkan pemahaman yang baik terhadap soal dan pemodelan matematika dalam penyelesaiannya. Hal ini dapat dilihat dari pencapaian hasil ulangan harian siswa pada pokok bahasan program linear di kelas XI, lebih dari 65\% siswa memperoleh nilai di bawah kriteria ketuntasan minimal yang ditetapkan sekolah yaitu 7.50. Soal ulangan harian yang diberikan terdiri dari 3 soal dengan 1 soal di antaranya berupa soal cerita yang penyelesaiannya membutuhkan kemampuan komunikasi matematis, karena untuk dapat menyelesaikan soal tersebut di antaranya siswa harus mampu menyatakan informasi pada soal cerita ke dalam bentuk tabel dan membuat model matematika dari soal cerita tersebut.

Pada proses penyelesaiannya siswa mengalami kesulitan pada tahap mengubah ide matematik dari soal ke dalam model matematika. Bahkan dari total 40 siswa kelas XI IIS 2 hanya 6 siswa atau $15 \%$ yang dapat membuat model matematika dari soal cerita yang ada dengan cukup baik dan $85 \%$ atau 34 siswa lainnya melakukan banyak kesalahan dalam membuat model matematika dari soal cerita tersebut. Setelah dilakukan wawancara dengan 8 orang siswa XI IIS 2 pada tanggal 16 April 2016 terkait masalah yang mereka hadapi ketika menyelesaikan soal cerita yang terdapat pada ulangan harian materi program linear sebelumnya, beberapa di antara mereka mengaku memahami informasi pada soal yang diberikan, tetapi mereka mengalami kesulitan untuk mengomunikasikan kembali ke dalam model matematika. Ada juga dari mereka yang sama sekali tidak memahami informasi pada soal dan tidak bisa untuk mengomunikasikan kembali kedalam model matematika. Kesulitan ini mengakibatkan siswa tidak bisa menyelesaikan soal dengan tepat.

Dari sekian banyak masalah dalam pembelajaran matematika, masalah soal cerita banyak ditemukan dalam pembelajaran matematika di kelas dan soal cerita sangat erat kaitannya dengan kemampuan komunikasi matematis. Soal cerita yang terdapat dalam matematika menurut Raharjo dan Astuti (Kurniawan,D., Yusmin,E., Hamdani., 2017) merupakan persoalan-persoalan yang terkait 
dengan permasalahan-permasalahan dalam kehidupan sehari-hari yang dapat dicari penyelesaiannya dengan menggunakan kalimat matematika.

Berdasarkan penelitian yang telah dilakukan, bahwa disalah satu SMP kabupaten Bandung Barat ini, gender siswa laki-laki masih tergolong rendah, dikarenakan dalam pembelajaran tersebut mereka kurangnya pengarahan dalam penyelesaian soal-soal cerita terebut.Penelitian ini dilakukan di SMP Pasundan Rongga, jika dilihat dari hasil penelitian, materi "Perbandingan" ini termasuk materi yang sulit dan belum dikuasai oleh siswa, sehingga menyebabkan rendahnya kualitas pembelajaran siswa, karena dalam mengerjakan soal yang berbentuk cerita sangatlah diperlukan ketelitian dalam membaca soal dan kreatifitas yang tinggi untuk menyelesaikannya.

Hal ini sejalan dengan hasil penelitian yang dilakukan oleh (Marlina, dkk 2018) di kelas VII MTs, kualitas pembelajaran materi perbandingan di sekolah yang diteliti masih tergolong rendah, hal itu terjadi karena kurangnya pembelajaran yang diawali dengan suatu permasalahan nyata dan siswapun kurang diarahkan untuk menyelesaikan soal atau masalah melalui penyelidikan. Tidak dipungkiri matematika menjadi salah satu mata pelajaran dengan tingkat kesulitan belajar yang paling banyak dialami siswa. Oleh karena itu perlu penelusuran lebih dalam terhadap apa saja hambatan belajar siswa sehingga mengalami kesulitan mengerjakan soal matematika, terutama pada soal yang berbentuk soal cerita. Menyikapi hal tersebut maka penulis melakukan studi pendahuluan untuk mengetahui bentukbentuk kesalahan dalam menyelesaikan soal cerita siswa SMP di salah satu sekolah di Kabupaten Bandung Barat pada materi perbandingan.

\section{METODE}

Metode penelitian ini merupakan penelitian studi kasus, karena tujuan dari penelitian ini untuk mengetahui bentuk-bentuk kesalahan yang dilakukan oleh siswa dalam mengerjakan soal cerita. Penelitian dilaksanakan di sekolah SMP Pasundan Rongga pada semester ganjil bulan November tahun pelajaran 2019/2020. Subjek dalam penelitian adalah siswa kelas VIII A. Teknik pengumpulan data dalam penelitian yaitu teknik langsung, artinya bahwa peneliti meneliti langsung terhadap objek yang ditelitinya,dan data yang digunakan dalam penelitian ini yaitu berupa tes soal cerita terkait materi perbandingan. Selanjutnya tahapan dalam penelitian studi kasus ini yaitu untuk menganalisis bentukbentuk kesalahan berdasarkan pada langkah-langkah dalam mengerjakan soal cerita, apakah siswa tersebut bisa menyelesaikan soal dengan benar dan tepat, apakah siswa tersebut bisa menyelesaikan sesuai dengan intruksi soal yang diminta, dan siswa tersebut apakah siswa tersebut bisa menyelesaikan soal dengan pemodelan matematikanya, karena didalam soal cerita itu sangatlah diperlukan ketelitian, pemahaman, dan keterampilan yang jeli dalam menyelesaikan permasalahan soal cerita.

\section{HASIL}

Hasil penelitian yang dideskripsikan terhadap penelitian ini adalah analisis kesalahan yang mengacu pada pada langkah-langkah dalam mengerjakan soal cerita, apakah siswa tersebut bisa 
menyelesaikan soal dengan benar dan tepat, apakah siswa tersebut bisa menyelesaikan sesuai dengan intruksi soal yang diminta, dan siswa tersebut apakah bisa menyelesaikan soal dengan pemodelan matematikanya, karena didalam soal cerita itu sangatlah diperlukan ketelitian, pemahaman, dan keterampilan yang jeli dalam menyelesaikan permasalahan soal cerita. Subjek penelitian ini adalah siswa kelas VIII A SMP Pasundan Rongga, siswa laki-laki dan siswa perempuan masing-masing terdiri dari 3 orang. Berdasarkan pengumpulan data selama penelitian di SMP Pasundan Rongga kelas VIII A diperoleh data mengenai hasil tes materi perbandingan yang berbentuk soal cerita.

Berikut ini hasil analisis kesalahan siswa laki-laki dan perempuan yang dilakukan peneliti pada hasil tes siswa dengan mengidentifikasikan seberapa besar persentase nilai kesalahan pada pengerjaan soal cerita dari setiap gendernya.

Tabel 1.

Data Kesalahan Siswa Laki-laki Tiap Soal

\begin{tabular}{|llllll|}
\hline No Soal & Siswa 1 & Siswa 2 & Siswa 3 & Total & Persentase (\%) \\
\hline 1 & 27 & 20 & 30 & 77 & 85,56 \\
\hline 2 & 35 & 35 & 40 & 110 & 91,67 \\
\hline 3 & 25 & 25 & 30 & 80 & 88,89 \\
\hline
\end{tabular}

Berdasarkan tabel di atas, merupakan kesalahan-kesalahan yang dilakukan oleh siswa laki-laki dalam menyelesaikan soal cerita terkait materi perbandingan dengan berjumlah 3 butir soal yang berbentuk uraian. Dari soal pertama, terlihat bahwa siswa satu melakukan kesalahan sebanyak 27 , kesalahan yang dilakukan oleh siswa tersebut yaitu terletak pada langkah-langkah dalam menyelesaikan soal tentang perbandingan pada skala peta, jadi dalam soal tersebut siswa sudah hampir mendekati pada jawaban benar tetapi proses dan langkah-langkahnya kurang tepat, siswa dua melakukan kesalahan sebanyak 20 , kesalahan yang dilakukan oleh siswa tersebut yaitu letak kesalahannya terletak pada langkah-langkah dalam menyelesaikan soal tentang perbandingan pada skala peta, jadi dalam soal tersebut siswa sudah hampir mendekati pada jawaban benar tetapi sangat disayangkan penulisan langkah-langkah yang dituliskan oleh siswa kurang tepat walaupun jawaban akhirnya hampir benar, selanjutnya siswa tiga melakukan kesalahan sebanyak 30, kesalahan yang dilakukan oleh siswa tersebut yaitu siswa kurang memahami dan tidak teliti dalam membaca soal, sehingga mengakibatkan pada jawaban siswa tidak sesuai dengan apa yang ditanyakan dari soal tersebut. Jadi jumlah kesalahan yang dilakukan oleh ketiga siswa tersebut adalah sebanyak 77. Pada soal kedua, terlihat bahwa siswa satu melakukan kesalahan sebanyak 35,kesalahan yang dilakukan oleh siswa tersebut yaitu terletak dalam menuliskan apa yang diketahui dari soal, yang seharusnya dari soal itu jaraknya 40 tetapi siswa malah menuliskan 80, disamping itu siswa juga salah dalam menuliskan langkah-langkah dalam menyelesaikan soal tersebut, siswa dua melakukan kesalahan yang sama dengan siswa satu yaitu sebanyak 35, kesalahan yang dilakukan oleh siswa tersebut yaitu terletak pada saat siswa menuliskan 
rumus,siswa tiga melakukan kesalahannya sebanyak 40, kesalahan yang dilakukan oleh siswa tersebut yaitu saat menuliskan diketahui,ditanyakan dari soal dan siswa tidak menjawab sesuai dengan intruksi soal yang diminta. Jadi jumlah kesalahan yang dilakukan oleh ketiga siswa tersebut yaitu sebanyak 110 .

Pada soal ketiga atau soal yang terakhir, terlihat bahwa siswa satu melakukan kesalahan sebanyak 25, kesalahan yang dilakukan oleh siswa tersebut yaitu siswa tidak teliti saat menuliskan apa yang ditanyakan sehingga dalam pengerjaannya tidak sesuai dengan apa yang diminta dari soal, siswa dua melakukan kesalahan yang sama dengan siswa satu yaitu sebanyak 25, kesalahan yang dilakukan oleh siswa tersebut sama dengan yang dilakukan oleh siswa satu yaitu siswa tidak teliti saat menuliskan apa yang ditanyakan sehingga dalam pengerjaannya tidak sesuai dengan apa yang diminta dari soal dan siswa ketiga melakukan kesalahannya yaitu sebanyak 30, kesalahan yang dilakukan oleh siswa tersebut yaitu siswa tidak teliti dalam menghitung perbedaan jarak sehingga jawaban siswapun tidak benar.Jadi jumlah kesalahan yang dilakukan oleh siswa tersebut yaitu sebanyak 110 .

Selanjutnya dapat disimpulkan bahwa persentase kesalahan-kesalahan yang dilakukan oleh siswa laki-laki terhadap soal cerita terkait materi perbandingan pada soal pertama, persentase kesalahan yang dilakukan oleh siswa satu,siswa dua dan siswa tiga adalah sebanyak $85,56 \%$,persentase pada soal kedua,kesalahan yang dilakukan oleh siswa satu, siswa dua dan siswa tiga adalah sebanyak 91,67\%, dan persentase pada soal ketiga, kesalahan yang dilakukan oleh siswa satu, siswa dua, dan siswa tiga adalah sebanyak $88,67 \%$.

\section{Tabel 2.}

Data Kesalahan Siswa Perempuan Tiap Soal

\begin{tabular}{|llllll|}
\hline No Soal & Siswa 1 & Siswa 2 & Siswa 3 & Total & Persentase (\%) \\
\hline 1 & 10 & 20 & 20 & 50 & 55,56 \\
\hline 2 & 25 & 0 & 30 & 55 & 45,83 \\
\hline 3 & 15 & 10 & 20 & 45 & 50 \\
\hline
\end{tabular}

Berdasarkan tabel di atas, merupakan kesalahan-kesalahan yang dilakukan oleh siswa perempuan dalam menyelesaikan soal cerita terkait materi perbandingan dengan berjumlah 3 butir soal yang berbentuk uraian. Dari soal pertama, terlihat bahwa siswa satu melakukan kesalahan yaitu sebanyak 10, kesalahan yang dilakukan oleh siswa tersebut yaitu siswa tidak teliti dalam menghitung jarak perjalanan yang ditempuh, siswa dua melakukan kesalahan sebanyak 20, kesalahan yang dilakukan oleh siswa tersebut yaitu siswa salah dalam menghitung dan siswa tidak fokus terhadap apa yang ditanyakan dari soal, dan siswa tiga melakukan kesalahan yang sama dengan siswa dua yaitu sebanyak 20, kesalahan yang dilakukan oleh siswa tersebut sama dengan siswa dua yaitu siswa salah dalam menghitung dan siswa tidak fokus terhadap apa yang ditnyakan dari soal.

Jumlah kesalahan yang dilakukan oleh ketiga siswa tersebut adalah sebanyak 50. Pada soal kedua, terlihat bahwa siswa satu melakukan kesalahan yaitu sebanyak 25, kesalahan yang dilakukan 
oleh siswa tersebut yaitu siswa tidak teliti dalam menuliskan rumus sehingga siswa tesebut salah dalam proses perhitungannya, siswa dua tidak melakukan kesalahan (dikarenakan soalnya terjawab dengan benar dan tepat), dan siswa tiga melakukan kesalahan sebanyak 30, kesalahan yang dilakukan oleh siswa tersebut yaitu siswa keliru dalam menuliskan rumus dan siswa tidak teliti saat menuliskan apa yang ditanyakan dari soal, sehingga siswa tesebut tidak menjawab dengan benar dan salah jug a dalam proses perhitungannya. Jadi total kesalahan yang dilakukan oleh ketiga siswa tersebut adalah sebanyak 55.Pada soal ketiga atau soal yang terakhir, terlihat bahwa siswa satu melakukan kesalahan yaitu sebanyak 15 , kesalahan yang dilakukan oleh siswa tersebut yaitu siswa tidak menyelesaikan soal sampai akhir, siswa dua melakukan kesalahan sebanyak 10, kesalahan yang dilakukan oleh siswa tersebut yaitu siswa tidak teliti dalam proses perhitungan dan siswa ketiga melakukan kesalahannya sebanyak 20, kesalahan yang dilakukan oleh siswa tersebut yaitu siswa tidak teliti dalam menuliskan apa yang diminta dari soal. jadi jumlah kesalahan yang dilakukan oleh ketiga siswa tersebut adalah sebanyak 45 .

Selanjutnya dapat disimpulkan bahwa persentase kesalahan-kesalahan yang dilakukan oleh siswa perempuan terhadap soal cerita terkait materi perbandingan, pada soal pertama persentase kesalahan yang dilakukan oleh siswa satu,siswa dua, dan siswa tiga adalah sebanyak 55,56\%, persentase pada soal kedua, kesalahan yang dilakukan oleh siswa satu, siswa dua dan siswa tiga adalah sebanyak $45,83 \%$, persentase kesalahan pada soal ketiga yang dilakukan oleh siswa satu, siswa dua dan siswa tiga adalah sebanyak $50 \%$.

Jadi, kesimpulan berdasarkan kedua tabel tersebut, persentase kesalahan-kesalahan yang dilakukan oleh siswa laki-laki dan siswa perempuan terlihat bahwa dari siswa laki-laki memiliki tingkat kesalahan-kesalahan yang paling tinggi dibanding dengan siswa perempuan, dapat dikatakan bahwa penelitian di SMP Pasundan Rongga ini siswa laki-lakinya memang tergolong kategori rendah dalam menyelesaikan suatu soal cerita yang terkait materi perbandingan.

Kesalahan-kesalahan siswa pada saat mengerjakan soal cerita memang sering terjadi, dikarenakan soal cerita lebih sulit jika dibandingkan dengan soal-soal biasa, maka dari itu timbullah siswa mengalami kebingungan saat mengerjakan soal cerita, dan pada akhirnya siswa yang sama sekali tidak bisa menjawab soal tersebut,dam ada juga siswa yang hanya menuliskan diketahui dan ditanyakannya dari soal, bahkan ada juga siswa yang hanya mencoret-coret kertas saja. Berikut ini beberapa kesalahan yang dilakukan siswa laki-laki dan perempuan dalam menyelesaikan soal cerita terkait materi perbandingan.

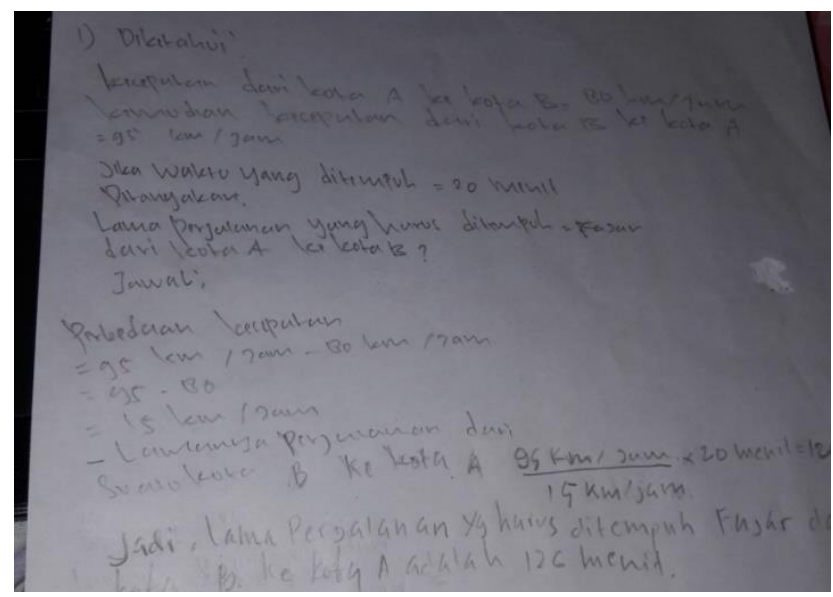




\section{Gambar 1. Salah Satu Jawaban Dari Siswa Laki-Laki}

Pada Gambar 1 ini, adalah jawaban dari salah satu siswa laki-laki . Berdasarkan jawaban siswa lakilaki tersebut, dari mulai diketahui dan ditanyakannya sudah tepat dan sesuai dengan soal, tetapi sangat disayangkan siswa tersebut kurang teliti dalam membaca dan menguasai soal, maka terlihat pada jawaban akhir bahwa siswa tidak fokus terhadap pertanyaan, karena seharusnya di soal itu yang ditanyakan adalah lamanya perjalanan dari kota A ke kota B tetapi siswa tersebut tidak memahami apa yang seharusnya menjadi penilaian peneliti. Jadi bisa ditarik kesimpulan bahwa dari jawaban siswa tersebut memang tidak sepenuhnya terjawab dengan benar.

Karena penyelesaian soal cerita itu memerlukan langkah-langkah awal yaitu membaca soal dengan cermat, memisahkan apa yang diketahui dan ditanyakan pada soal, menyelesaikan dan membuat model matematika, serta mengembalikan jawaban model matematika kepada jawaban soal aslinya (Toha,M., Mirza,A., Ahmad,D., 2018).

Bisa ditarik kesimpulan bahwa siswa dalam menjawab soal terkait perbandingan ini siswa memang sudah mampu menguasai konsep dengan baik, hanya saja siswa kurang teliti dalam memahami soal tersebut.

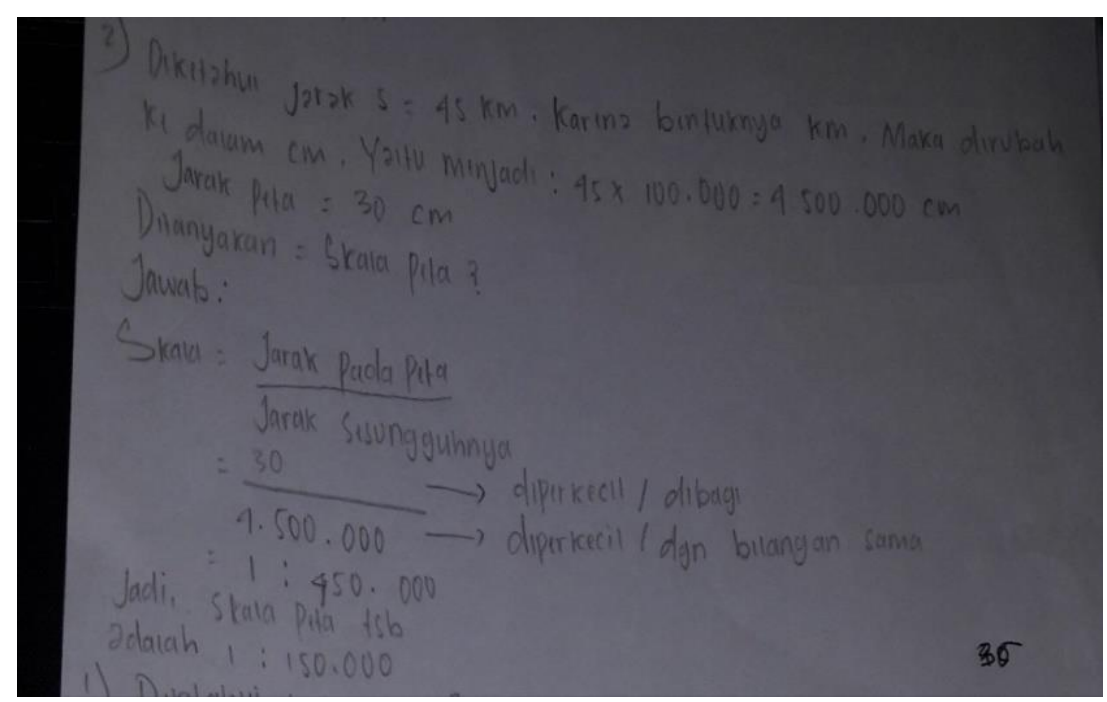

Gambar 2. Salah Satu Jawaban dari Siswa Perempuan

Gambar 2 adalah jawaban dari siswa perempuan, dimana dalam ilustrasi tersebut terlihat bahwa jawaban siswa memang sudah maksimal terjawab dengan tepat tetapi pada jawaban akhir, siswa sepertinya terlalu tergesa-gesa atau memang siswa lupa cara menyelesaikan variasi soal berbentuk pecahan atau perbandingan, karena sangat disayangkan siswa tersebut sudah mendekati jawaban benar tetapi ceroboh dalam hasil akhirnya, karena mungkin menurutnya bahwa variasi yang berbentuk pecahan itu dia berpikirnya pembilang dibagi pembilang tetapi yang penyebut juga dubagi dengan penyebut itu sendiri, padahal seharusnya jika pembilang dibagi pembilang maka penyebutnya juga harus sama dibagi dengan bilangan pembilang. Jadi intinya jawaban sudah betul, dari mulai cara 
diketahui dan ditanyakannya pun sudah tepat menuliskannya, terlihat juga dari jawaban di atas siswa menuliskan "karena bentuknya satuan km, harus di ubah menjadi satuan cm" bisa disimpulkan juga bahwa siswa tersebut sudah bisa memahami dan paham terhadap konsep perbandingan.

\section{KESIMPULAN}

Penelitian ini dilakukan di SMP Pasundan Rongga pada bulan November 2019. Subjek penelitian adalah siswa kelas VIII A tahun akademik 2019/2020. Pemilihan sampel didasarkan pada siswa lakilaki dan perempuan. Penelitian ini menggunakan penelitian studi kasus yang bertujuan untuk mengetahui bentuk-bentuk kesalahan yang dilakukan siswa kelas VIII A di SMP Pasundan Rongga dalam menyelesaikan soal cerita yang terkait dengan materi perbandingan.Berdasarkan hasil dari penelitian yang telah dilakukan maka terdapat beberapa bentuk kesalahan yang dilakukan siswa diantaranya kesalahan siswa laki laki pada soal nomor 1 sebanyak 85,56\%, kesalahan pada soal nomor 2 sebanyak 91,67\%, kesalahan pada soal nomor 3 sebanyak 88,67\%, sedangkan kesalahan siswa perempuan pada soal nomor 1 sebanyak 55,56\%, kesalahan pada soal nomor 2 sebanyak 45,83\%, dan kesalahan pada soal nomor 3 sebanyak 50\%.Berdasarkan hasil analisis data diperoleh kesimpulan dari sampel setiap gender, bahwa siswa laki-laki memiliki tingkat kesalahan yang tinggi dibanding dengan siswa perempuan, dan pada saat diwawancarai juga mengatakan bahwa di dalam soal cerita itu mereka rendah dalam menguasai soal, kurang mengetahui apa makna dari soal, ada juga siswa yang melakukan beberapa kesalahan dalam perhitungan dan siswa juga kebanyakan kurang mengetahui terhadap soal dan apa yang harus dicari dari soal-soal tersebut.

\section{DAFTAR PUSTAKA}

Chronika, A., Manalu, S., \& Zanthy, L. S. (2020). Analisis Kesalahan Siswa SMP Kelas IX Dalam Menyelesaikan Soal Materi Lingkaran. 04(01), 104-112.

Eftafiyana, dkk. (2018). Hubungan Antara Kemampuan Berpikir Kreatif Matematis Dan Motivasi Belajar Siswa Smp Yang Menggunakan Pendekatan Creative Problem Solving. Teorema, 2(2), 85. https://doi.org/10.25157/.v2i2.1070

Fitria, N. F. N., Hidayani, N., Hendrian, H., \& Amelia, R. (2018). Analisis Kemampuan Pemecahan Masalah Matematik Siswa SMP Dengan Materi Segitiga dan Segiempat. Edumatica, 08(1), 4957. https://online-journal.unja.ac.id/index.php/edumatica

Hamidah, D., Putri, R. I. I., \& Somakim, S. (2018). Eksplorasi Pemahaman Siswa pada Materi Perbandingan Senilai Menggunakan Konteks Cerita di SMP. Jurnal Riset Pendidikan Dan Inovasi Pembelajaran Matematika (JRPIPM), 1(1), 1. https://doi.org/10.26740/jrpipm.v1n1.p1-10

Indahsari, I. N., Situmorang, J. C., \& Amelia, R. (n.d.). Analisis kemampuan Pemecahan Masalah Matematis dan Self Efficacy Siswa MAN. Journal On Education, 01(02), 256-264.

Kurniawan, D., Yusmin, E., \& Hamdani. (2017). Deskripsi Kemampuan Komunikasi Matematis Siswa Dalam Menyelesaikan Soal Cerita Kontekstual. Jurnal Pendidikan Dan Pembelajaran, 6(2), 1- 
11.

Marlina, R., Nurjahidah, S., Sugandi, A. I., \& Setiawan, W. (2018). Penerapan Pendekatan Problem Based Learning Untuk Meningkatkan Kemampuan Pemecahan Masalah Matematis Siswa Kelas VII MTS Pada Materi Perbandingan Dan Skala. JPMI (Jurnal Pembelajaran Matematika Inovatif), 1(2), 113. https://doi.org/10.22460/jpmi.v1i2.p113-122

Mentari Dini , Tommy Tanu Wijaya, A. I. S. (2018). Pengaruh Self Confidence Terhadap Kemampuan Pemahaman Matematik Siswa SMP. Artikel: Jurnal Silogisme Universitas Muhammadiyah Ponorogo, 3(1), 1-7. http://journal.umpo.ac.id/index.php/silogisme

Mulyanti, N. R., Yani, N., \& Amelia, R. (2018). Analisis Kesulitan Siswa Dalam Pemecahan Masalah Matematik Siswa SMP Pada Materi Teorema Phytagoras. JPMI (Jurnal Pembelajaran Matematika Inovatif), 1(3), 415. https://doi.org/10.22460/jpmi.v1i3.p415-426

Oktaviana, D. (2018). Analisis Tipe Kesalahan Berdasarkan Teori Newman Dalam Menyelesaikan Soal Cerita Pada Mata Kuliah Matematika Diskrit. Edu Sains: Jurnal Pendidikan Sains \& Matematika, 5(2), 22. https://doi.org/10.23971/eds.v5i2.719

Rachman, F, A., S. (2020). Analisis Kesalahan Siswa Kelas XI Pada Materi Trigonometri. 04(01), 126133.

Toha, M., Mirza, A., \& Ahmad, D. (2018). Analisis Kesalahan Siswa dalam Menyelesaikan Soal Cerita Materi Perbandingan di Kelas VII SMP. Jurnal Pendidikan Dan Pembelajaran, 7(1), 1-10.

Yusdiana, B. I., \& Hidayat, W. (2018). Analisis Kemampuan Penalaran Matematis Siswa SMA Pada Materi Limit Fungsi. JPMI (Jurnal Pembelajaran Matematika Inovatif), 1(3), 409. https://doi.org/10.22460/jpmi.v1i3.p409-414

Zannati, G. N., Fitrianna, A. Y., \& Rohaeti, E. E. (2018). Analisis Kemampuan Komunikasi Matematis Siswa SMP Berdasarkan Gender Dan Self Concept. Jurnal Pendidikan Matematika Inovatif, 1(2), 107-112. https://doi.org/10.22460/jpmi.v1i2.93-218

Zulfah. (2017). Analisis Kesalahan Peserta Didik Pada Materi Persamaan Linear Dua Variabel Di Kelas VIII MTS Negeri Sungai Tonang. 1(1), 12-16. 